\title{
The Electrocardiogram in Complete Transposition of the Great Vessels
}

\author{
REDA M. SHAHER* AND DENNIS C. DEUCHAR \\ From the Cardiac Department, Guy's Hospital, London S.E.I
}

The electrocardiogram in complete transposition of the great vessels has been discussed by several authors (Campbell and Suzman, 1951; Astley and Parsons, 1952; Wood, 1956; Keith, Rowe, and Vlad, 1958; Noonan et al., 1960; Elliott et al., 1963a; Calleja, Hosier, and Grajo, 1965; and others). Most authors correlated the electrocardiogram with the underlying pathology of the ventricular septum and the presence or absence of pulmonary stenosis, while Elliott et al. (1963a) correlated their findings with the size of the associated defects at necropsy. Little attempt, however, has been made to correlate the electrocardiogram with the hæmodynamics of the circulation and the pathology of the heart. This study aims to make this correlation and is confined to complete transposition of the great vessels with normal position of the atria and of the ventricles, as defined in the classification suggested by Shaher and Johnson (1963), and Shaher (1964a). Patients with associated single ventricle or with tricuspid atresia have been excluded.

\section{SUBJECTS}

The electrocardiograms of 33 patients with complete transposition of the great vessels were available: standard and præcordial leads had been recorded in 31, but standard leads only in 2 (Patients 6 and 12). Four patients were from Southampton Chest Hospital and 29 from Guy's Hospital. The diagnosis had been confirmed by necropsy in 23, by angiography and/or cardiac catheterization in 5, by operation in 2, by operation and cardiac catheterization in 2, and by cardiac catheterization, angiocardiography, and operation in 1. Thirteen patients were less than 1 year old, 6 were between 1 and 10 years, 8 were between 10 and 20 years, and 6 were between 20 and 30 years. All patients had situs

\footnotetext{
Received May 11, 1965.

$\star$ Present address: Cardiology Department, Hospital for Sick Children, Toronto, Canada.
}

solitus of the heart and of the viscera, and they have been classified into 3 groups according to the presence or absence of a ventricular septal defect and the presence or absence of pulmonary stenosis.

Group I. Closed ventricular septum without pulmonary stenosis: 9 patients (præcordial leads in 8 only) (Table I).

Group II. Ventricular septal defect, without pulmonary stenosis: 16 patients (præcordial leads in 15 only) (Table II).

Group III. Ventricular septal defect and pulmonary stenosis: 8 patients (Table III).

Criteria. The axis of the QRS complex was considered to be normal in the age-group under 1 year to 16 years, if this lay within plus or minus 30 degrees from the following average normal values of Ziegler (1951):

$\begin{array}{rrrr}0-24 \mathrm{hr} . & +137^{\circ} & 1-3 \mathrm{yr} . & +62^{\circ} \\ 1 \text { day-1 wk. } & +128^{\circ} & 3-5 \mathrm{yr} . & +64^{\circ} \\ 1 \text { wk. }-1 \text { mth. } & +105^{\circ} & 5-8 \mathrm{yr} . & +69^{\circ} \\ 1-3 \text { mth. } & +76^{\circ} & 8-12 \mathrm{yr} . & +64^{\circ} \\ 3-6 \text { mth. } & +67^{\circ} & 12-16 \mathrm{yr} . & +66^{\circ} \\ 6 \text { mth. }-1 \text { yr. } & +64^{\circ} & & \end{array}$

In adults above the age of 16 years a normal axis was considered present if it ranged from 0 to $+60^{\circ}$. In all age-groups the limit between extreme right axis deviation and extreme left axis deviation is considered to be $-90^{\circ}$. According to Martins de Oliveira and Zimmerman (1959) the normal P wave in limb leads should not exceed $0.10 \mathrm{sec}$. in duration and $2.5 \mathrm{~mm}$. in amplitude. The $P$ vector is supposed usually to lie between +30 and $+75^{\circ}$, though a wider range to the left has been described in normal subjects, but never exceeding $-30^{\circ}$. The normal P-R interval for the age-group 0 to 16 years has been averag $d$ out from the normal values of Ziegler (1951). In adults the normal P-R interval was accepted to vary from 0.12 to $0.20 \mathrm{sec}$. (Wood, 
TABLE I

NINE PATIENTS WITH A CLOSED VENTRICULAR SEPTUM

\begin{tabular}{|c|c|c|c|c|c|c|c|c|c|c|c|c|}
\hline \multirow{2}{*}{$\begin{array}{l}\text { Patient } \\
\text { No. }\end{array}$} & \multirow{2}{*}{ Age } & \multirow{2}{*}{$\begin{array}{l}\text { Method of } \\
\text { diagnosis }\end{array}$} & \multirow{2}{*}{ Axis * } & \multicolumn{3}{|c|}{$P$ wave } & \multirow{2}{*}{$\begin{array}{c}\mathbf{P}-\mathbf{R} \\
(\mathrm{sec} .)\end{array}$} & \multirow{2}{*}{$\begin{array}{l}\text { QRS } \\
\text { (sec.) }\end{array}$} & \multirow{2}{*}{$\begin{array}{l}\text { Ven- } \\
\text { tricular } \\
\text { hyper- } \\
\text { trophyt }\end{array}$} & \multirow{2}{*}{$\begin{array}{l}\text { Q V1 } \\
(\mathrm{mm} .)\end{array}$} & \multirow{2}{*}{$\mid \begin{array}{c}\text { Q V6 } \\
\text { (mm.) }\end{array}$} & \multirow{2}{*}{ Præcordial T } \\
\hline & & & & Vector & $\mid \begin{array}{c}\text { Height } \\
\text { (mm.) }\end{array}$ & $\left|\begin{array}{c}\text { Duration } \\
\text { (sec.) }\end{array}\right|$ & & & & & & \\
\hline $\begin{array}{l}1 \\
2 \\
3 \\
4 \\
5 \\
6 \\
7 \\
8 \\
9\end{array}$ & $\begin{array}{l}2 \text { wk. } \\
6 \text { wk. } \\
2 \text { mth. } \\
2 \text { mth. } \\
3 \text { mth. } \\
3 \text { mth. } \\
5 \text { mth. } \\
10 \frac{1}{2} \mathrm{yr} . \\
16 \text { yr. }\end{array}$ & $\begin{array}{l}\text { Necropsy } \\
\text { Necropsy } \\
\text { Necropsy } \\
\text { Necropsy } \\
\text { Necropsy } \\
\text { Necropsy } \\
\text { Necropsy } \\
\text { Necropsy } \\
\text { Catheter }\end{array}$ & $\begin{array}{c}\text { Normal axis }+120^{\circ} \\
\text { RAD }+120^{\circ} \\
\text { RAD }+120^{\circ} \\
\text { RAD }+120^{\circ} \\
\text { Open } \\
\text { RAD }+120^{\circ} \\
\text { RAD }+120^{\circ} \\
\text { RAD }-180^{\circ} \\
\text { RAD }-180^{\circ}\end{array}$ & $\begin{array}{l}+60^{\circ} \\
+60^{\circ} \\
+60^{\circ} \\
+60^{\circ} \\
+60^{\circ} \\
+60^{\circ} \\
+60^{\circ} \\
+60^{\circ} \\
+60^{\circ}\end{array}$ & $\begin{array}{l}2 \\
3 \\
2 \\
5 \\
3 \\
4 \\
6 \\
4 \\
3\end{array}$ & $\begin{array}{l}0.06 \\
0.06 \\
0.06 \\
0.06 \\
0.06 \\
0.06 \\
0.06 \\
0.08 \\
0.06\end{array}$ & $\begin{array}{l}0 \cdot 16 \\
0.12 \\
0.12 \\
0 \cdot 12 \\
0 \cdot 10 \\
0 \cdot 12 \\
0 \cdot 12 \\
0 \cdot 16 \\
0 \cdot 16\end{array}$ & $\begin{array}{l}0.06 \\
0.04 \\
0.06 \\
0.04 \\
0.06 \\
0.06 \\
0.08 \\
0.08 \\
0.06\end{array}$ & $\begin{array}{l}\text { N } \\
\text { RVH } \\
\text { RVH } \\
\text { N } \\
\text { CVH } \\
\text { RVH } \\
\text { RVH } \\
\text { RVH }\end{array}$ & $\begin{array}{l}\bar{z} \\
\bar{Z} \\
\overline{3} \\
\frac{2}{2}\end{array}$ & $\begin{array}{l}\frac{1}{1} \\
\frac{5}{-}\end{array}$ & $\begin{array}{l}\text { - ve V1-6 } \\
\text { + ve V1-6 } \\
\text { - ve V1-6 } \\
\text { + ve V2-6 } \\
\text { + ve V1-6 } \\
\text { + ve V1-6 } \\
\text { - ve V1, + ve V6 } \\
\pm V 1,+ \text { ve V6 }\end{array}$ \\
\hline
\end{tabular}

$\star$ RAD is right axial deviation.

t RVH is right ventricular hypertrophy; $\mathrm{CVH}$ is combined ventricular hypertrophy; $\mathrm{N}$ is normal for age.

TABLE II

SIXTEEN PATIENTS WITH A VENTRICULAR SEPTAL DEFECT WITHOUT PULMONARY STENOSIS

\begin{tabular}{|c|c|c|c|c|c|c|c|c|c|c|c|c|c|}
\hline \multirow{2}{*}{$\begin{array}{c}\text { Patient } \\
\text { No. }\end{array}$} & \multirow{2}{*}{ Age } & \multirow{2}{*}{$\begin{array}{l}\text { Method of } \\
\text { diagnosis }\end{array}$} & \multirow{2}{*}{ Axis } & \multicolumn{3}{|c|}{ P wave } & \multirow{2}{*}{$\begin{array}{c}\mathbf{P}-\mathbf{R} \\
(\mathrm{sec} .)\end{array}$} & \multirow{2}{*}{$\begin{array}{l}\text { QRS } \\
\text { (sec.) }\end{array}$} & \multirow{2}{*}{$\begin{array}{l}\text { Ven- } \\
\text { tricular } \\
\text { hyper- } \\
\text { trophy }\end{array}$} & \multirow{2}{*}{\begin{tabular}{|} 
Q V1 \\
(mm.)
\end{tabular}} & \multirow{2}{*}{$\begin{array}{c}\text { Q V6 } \\
\text { (mm.) }\end{array}$} & \multirow{2}{*}{$\begin{array}{l}\text { Form } \\
\text { of V1 }\end{array}$} & \multirow{2}{*}{$\underset{T}{\text { Præcordial }}$} \\
\hline & & & & Vector & $\underset{\text { (mm.) }}{\text { Height }}$ & $\left|\begin{array}{c}\text { Duration } \\
(\mathrm{sec} .)\end{array}\right|$ & & & & & & & \\
\hline 10 & 3 mth. & Necropsy & Normal axis & $+60^{\circ}$ & 3 & 0.06 & 0.12 & 0.04 & $\mathrm{CVH}$ & - & 3 & - & + ve $\mathrm{V} 1-6$ \\
\hline $\begin{array}{l}11 \\
12\end{array}$ & $\begin{array}{l}3 \text { mth. } \\
3 \text { mth. }\end{array}$ & $\begin{array}{l}\text { Necropsy } \\
\text { Necropsy }\end{array}$ & $\mathrm{RAD}^{+}+120^{\circ}$ & $\begin{array}{l}+60^{\circ} \\
+60^{\circ}\end{array}$ & $\begin{array}{l}4 \\
3\end{array}$ & $\begin{array}{l}0.08 \\
0.06\end{array}$ & $\begin{array}{l}0 \cdot 12 \\
0 \cdot 12\end{array}$ & $\begin{array}{l}0.04 \\
0.06\end{array}$ & RVH & - & 1 & 一 & + ve V1-6 \\
\hline $\begin{array}{l}13 \\
14 \\
15\end{array}$ & $\begin{array}{l}3 \mathrm{mth} \text {. } \\
6 \mathrm{mth} \text {. } \\
4 \frac{1}{2} \mathrm{yr}\end{array}$ & $\begin{array}{l}\text { Necropsy } \\
\text { Necropsy } \\
\text { Necropsy }\end{array}$ & $\begin{array}{l}\text { RAD }+120^{\circ} \\
\text { RAD }+120^{\circ} \\
\text { RAD }+150^{\circ}\end{array}$ & $\begin{array}{l}+60^{\circ} \\
+60^{\circ} \\
+60^{\circ}\end{array}$ & $\begin{array}{l}2 \\
2 \\
4\end{array}$ & $\begin{array}{l}0.06 \\
0.06 \\
0.08\end{array}$ & $\begin{array}{l}0 \cdot 16 \\
0 \cdot 12 \\
0 \cdot 16\end{array}$ & $\begin{array}{l}0.04 \\
0.06 \\
0.06\end{array}$ & $\begin{array}{l}\text { LVH } \\
\text { RVH } \\
\text { RVH }\end{array}$ & $\frac{-}{1}$ & $\frac{1}{1}$ & E & $\begin{array}{l}\text { + ve V1-6 } \\
\text { + ve V1-6 } \\
\text { - ve V1, }\end{array}$ \\
\hline $\begin{array}{l}16 \\
17\end{array}$ & $\begin{array}{r}4 \frac{1}{2} \text { yr. } \\
8 \text { yr. }\end{array}$ & $\begin{array}{l}\text { Necropsy } \\
\text { Necropsy }\end{array}$ & $\begin{array}{c}\text { Open } \\
\mathrm{RAD}-160^{\circ}\end{array}$ & $\begin{array}{l}+60^{\circ} \\
+60^{\circ}\end{array}$ & $\begin{array}{l}3 \\
5\end{array}$ & $\begin{array}{l}0.06 \\
0.08\end{array}$ & $\begin{array}{l}0 \cdot 12 \\
0 \cdot 12\end{array}$ & $\begin{array}{l}0.06 \\
0.06\end{array}$ & $\begin{array}{l}\text { RVH } \\
\text { RVH }\end{array}$ & - & 二 & $\underline{\mathbf{r S r}}$ & $\begin{array}{l}\text { + ve vo } \\
+ \text { ve V1-6 } \\
\text { - ve Vi, }\end{array}$ \\
\hline 18 & $10 \frac{1}{2} \mathrm{yr}$ & Angiocardio- & RAD - $190^{\circ}$ & $+60^{\circ}$ & 4 & 0.06 & $0 \cdot 16$ & 0.06 & RVH & - & QS & - & $\begin{array}{l}\text { - ve V1, } \\
\text { +ve V6 }\end{array}$ \\
\hline 19 & $13 \mathrm{yr}$. & $\begin{array}{l}\text { Catheter and } \\
\text { angiocardio- }\end{array}$ & RAD $-180^{\circ}$ & $+60^{\circ}$ & 3 & 0.08 & $0 \cdot 16$ & 0.06 & $\mathbf{N}$ & - & - & - & $\begin{array}{l} \pm \mathrm{V} 1 \text {, } \\
+ \text { ve V6 }\end{array}$ \\
\hline 20 & $15 \mathrm{yr}$. & $\begin{array}{l}\text { Catheter and } \\
\text { angiocardio- } \\
\text { graphy }\end{array}$ & $\mathrm{LAD}-80^{\circ}$ & $+60^{\circ}$ & 4 & 0.12 & $0 \cdot 16$ & 0.08 & $\mathrm{CVH}$ & - & 4 & $\mathbf{R s R}^{\prime}$ & $\begin{array}{l} \pm \mathrm{V} 1 \\
+\mathrm{ve}\end{array}$ \\
\hline $\begin{array}{l}21 \\
22\end{array}$ & $\begin{array}{l}16 \mathrm{yr} . \\
18 \mathrm{yr} .\end{array}$ & $\begin{array}{l}\text { Operation } \\
\text { Necropsy }\end{array}$ & $\begin{array}{l}\text { RAD + } 150^{\circ} \\
\text { RAD }-150^{\circ}\end{array}$ & $\begin{array}{l}+60^{\circ} \\
+60^{\circ}\end{array}$ & $\begin{array}{l}6 \\
5\end{array}$ & $\begin{array}{l}0.12 \\
0.08\end{array}$ & $\begin{array}{l}0.16 \\
0.24\end{array}$ & $\begin{array}{l}0.08 \\
0.08\end{array}$ & $\begin{array}{l}\text { RVH } \\
\text { CVH }\end{array}$ & 二 & $\begin{array}{l}2 \\
2\end{array}$ & $\begin{array}{l}\text { rsR's' } \\
\text { Slur }\end{array}$ & $\begin{array}{l}\text { + ve V1-6 } \\
\text { - ve V1, }\end{array}$ \\
\hline 23 & $23 \mathrm{yr}$. & Necropsy & $R A D+180^{\circ}$ & $+30^{\circ}$ & 3 & 0.06 & 0.16 & 0.08 & $\mathbf{R V H}$ & - & QS & $\mathbf{r s} \mathbf{R}^{\prime}$ & - ve V1, \\
\hline 24 & $25 \mathrm{yr}$. & Necropsy & $\operatorname{RAD}+100^{\circ}$ & $+60^{\circ}$ & 3 & $0 \cdot 10$ & $0 \cdot 24$ & 0.08 & RVH & - & - & Slur & $-\stackrel{+}{+}$ \\
\hline 25 & $26 \mathrm{yr}$. & Necropsy & $\mathrm{RAD}+180^{\circ}$ & $+60^{\circ}$ & 4 & 0.08 & $0 \cdot 16$ & $0 \cdot 10$ & $\mathrm{CVH}$ & 1 & 1 & - & $\begin{array}{l}\text { tve } \\
\pm \text { vil, } \\
+ \text { ve }\end{array}$ \\
\hline
\end{tabular}

TABLE III

EIGHT PATIENTS WITH A VENTRICULAR SEPTAL DEFECT AND PULMONARY STENOSIS

\begin{tabular}{|c|c|c|c|c|c|c|c|c|c|c|c|c|c|}
\hline \multirow{2}{*}{$\begin{array}{c}\text { Patient } \\
\text { No. }\end{array}$} & \multirow{2}{*}{ Age } & \multirow{2}{*}{$\begin{array}{l}\text { Method of } \\
\text { diagnosis }\end{array}$} & \multirow{2}{*}{ Axis } & \multicolumn{3}{|c|}{ P wave } & \multirow{2}{*}{$\begin{array}{c}\text { P-R } \\
(\text { sec. })\end{array}$} & \multirow{2}{*}{$\begin{array}{l}\text { QRS } \\
\text { (sec.) }\end{array}$} & \multirow{2}{*}{$\begin{array}{l}\text { Ven- } \\
\text { tricular } \\
\text { hyper- } \\
\text { trophy }\end{array}$} & \multirow{2}{*}{$\begin{array}{l}\text { Q V1 } \\
\text { (mm.) }\end{array}$} & \multirow{2}{*}{$\begin{array}{l}\text { Q V6 } \\
\text { (mm.) }\end{array}$} & \multirow{2}{*}{$\begin{array}{l}\text { Form } \\
\text { of V1 }\end{array}$} & \multirow{2}{*}{$\underset{\mathbf{T}}{\text { Præcordial }}$} \\
\hline & & & & Vector & \begin{tabular}{|} 
Height \\
(mm.)
\end{tabular} & $\begin{array}{c}\text { Duration } \\
\text { (sec.) }\end{array}$ & & & & & & & \\
\hline $\begin{array}{l}26 \\
27\end{array}$ & $\begin{array}{l}8 \text { mth. } \\
8 \text { yr. }\end{array}$ & Necropsy & $\begin{array}{l}\text { RAD }-120^{\circ} \\
\text { RAD + } 150^{\circ}\end{array}$ & $\begin{array}{l}+60^{\circ} \\
+60^{\circ}\end{array}$ & $\begin{array}{l}3 \\
3\end{array}$ & $\begin{array}{l}0.06 \\
0.06\end{array}$ & $\begin{array}{l}0 \cdot 10 \\
0 \cdot 16\end{array}$ & $\begin{array}{l}0.06 \\
0.06\end{array}$ & $\begin{array}{l}\text { CVH } \\
\text { RVH }\end{array}$ & 二 & 1 & Slur & $\begin{array}{l}+ \text { ve V1-6 } \\
\pm \text { V1, }\end{array}$ \\
\hline 28 & $8 \mathrm{yr}$. & $\begin{array}{l}\text { Catheter, angio- } \\
\text { cardiography, } \\
\text { and operation }\end{array}$ & LAD $-60^{\circ}$ & $+30^{\circ}$ & 3 & 0.08 & $0 \cdot 16$ & 0.08 & LVH & QS & - & - & $\begin{array}{r}\text { + ve V6 } \\
+ \text { ve V1-6 }\end{array}$ \\
\hline 29 & 8 yr. & $\begin{array}{c}\text { Catheter and } \\
\text { operation }\end{array}$ & RAD - $120^{\circ}$ & $+60^{\circ}$ & 5 & 0.08 & $0 \cdot 20$ & 0.08 & RVH & - & - & Slur & - ve V1, \\
\hline 30 & $13 \mathrm{yr}$. & Operation & RAD $-160^{\circ}$ & $+30^{\circ}$ & 4 & 0.08 & 0.16 & 0.08 & RVH & - & - & - & $\pm \mathrm{V}_{1}$ \\
\hline 31 & $26 \mathrm{yr}$. & Necropsy & $\mathbf{R A D}+150^{\circ}$ & $+90^{\circ}$ & 5 & $0 \cdot 10$ & $0 \cdot 16$ & 0.08 & RVH & - & - & $\mathbf{r s} \mathbf{R}^{\prime}$ & $\begin{array}{r}\text { + ve V6 } \\
\text { - ve V1-5, }\end{array}$ \\
\hline 32 & $26 \mathrm{yr}$. & Angiocardio- & $R A D+150^{\circ}$ & $+30^{\circ}$ & 4 & 0.20 & 0.20 & $0 \cdot 10$ & RVH & - & - & $\mathbf{r s} \mathbf{R}^{\prime}$ & $\begin{array}{r}\text { + ve V6 } \\
\text { - ve V1, }\end{array}$ \\
\hline 33 & $29 \mathrm{yr}$. & $\begin{array}{l}\text { grapny } \\
\text { Necropsy }\end{array}$ & $R A D+120^{\circ}$ & $+60^{\circ}$ & 4 & 0.08 & 0.20 & $0 \cdot 10$ & RVH & - & - & $\mathbf{r s R ^ { \prime }}$ & $\begin{array}{l}\text { + ve V6 } \\
\text { - veV1-5, } \\
\pm \text { IV6 }\end{array}$ \\
\hline
\end{tabular}



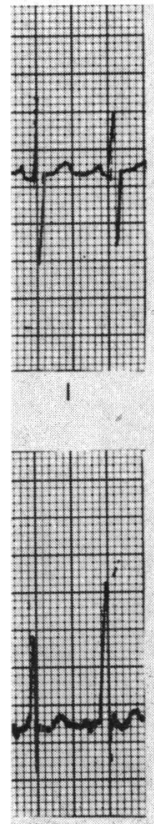

VI

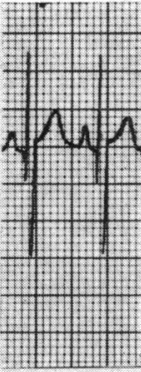

II

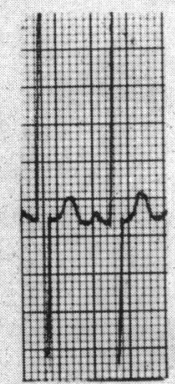

$\mathrm{V} 2$

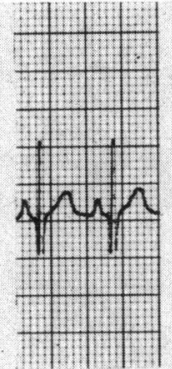

111

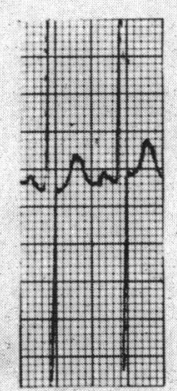

V3

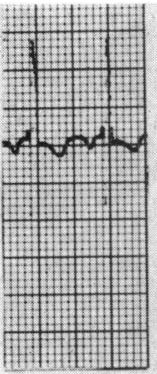

aVR

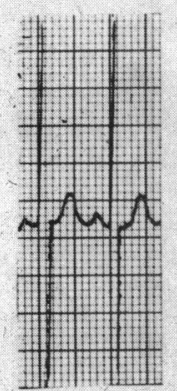

V4

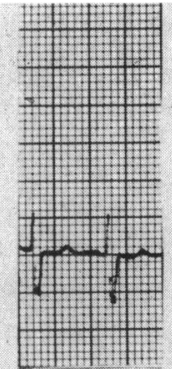

aVL

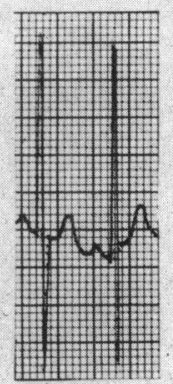

V5

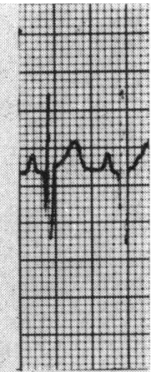

$a \vee F$

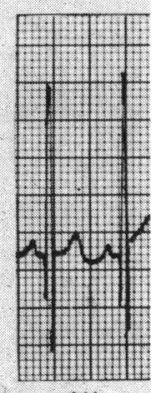

V6

FIG. 1.-Electrocardiogram of Patient 5, at 3 months, showing combined ventricular hypertrophy with deep QV6 and an undeterminable axis deviation.

1956). According to Ziegler (1951) and SodiPallares et al. (1958a) the QRS duration is slightly shorter in early childhood than in adults. The values range from 0.06 to $0.07 \mathrm{sec}$. up to the $3 \mathrm{rd}$ year of age, and from the 3rd to the 16th year the duration varies between 0.07 and $0.08 \mathrm{sec}$. In adults the whole QRS complex rarely exceeds 0.08 sec. in duration (Wood, 1956). According to Ziegler (1951) and Sodi-Pallares et al. (1958a), at birth the $T$ waves are upright in the right præcordial leads and frequently inverted in the left præcordial leads. Afterwards the waves gradually become negative in the right and positive in the left præcordial leads. The normal $\mathrm{T}$ wave changes in the age-group 0 to 16 years have been discussed in detail by Ziegler (1951). The criteria employed for signs of right, left, and combined ventricular hypertrophy are those suggested by Vince and Keith (1961), using the normal values of Ziegler (1951) for patients above 1 year and up to and including 16 years, of Scott and Franklin (1963) for infants below the age of 1 year (for these figures are based on a larger number of patients than those of Ziegler), and of Kossman and Johnston (1935) for patients above the age of 16 years. The presence of tall equiphasic complexes in the mid-præcordial leads over $50 \mathrm{~mm}$. in amplitude (Katz-Wachtel sign), which has been accepted by Katz, Langendorf, and Pick (1952), Sodi-Pallares and Calder (1956), Dack (1960),
Elliott, Taylor, and Schiebler (1963b), and Elliott et al. (1963a) to represent biventricular hypertrophy, has been used here also to indicate enlargement of both ventricles.

Findings. Detailed electrocardiographic measurements in each of the 3 groups are found in Tables I, II, and III, and the significant findings are as follows.

1. Rhythm. All 33 patients were in sinus rhythm.

2. $P$ Waves. (a) Maximum height (33 patients): This measurement was $2 \mathrm{~mm}$. in 4, $3 \mathrm{~mm}$. in 12, $4 \mathrm{~mm}$. in 10, $5 \mathrm{~mm}$. in 5, and $6 \mathrm{~mm}$. in 2 .

(b) Maximum duration (33 patients): This measurement was $0.06 \mathrm{sec}$. in $17,0.08 \mathrm{sec}$. in $12,0.10$ sec. in 2 , and 0.12 sec. in 2.

3. Electrical Axis (33 patients). Normal axis deviation was present in 3 , right axis deviation in 26 , left axis deviation in 2, and indeterminate axis in 2.

4. Ventricular Hypertrophy Pattern: Pracordial Leads (31 patients). In the group of 8 with a closed ventricular septum, there was no evidence of ventricular hypertrophy in 2, but 5 showed evidence of right ventricular hypertrophy, and one of combined ventricular hypertrophy (Fig. 1).

In the group of 15 with a ventricular septal defect without pulmonary stenosis, normal ventricular pattern was present in 1, right ventricular hypertrophy 


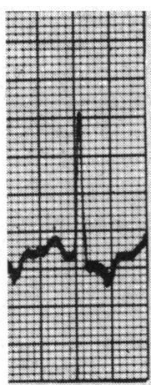

1

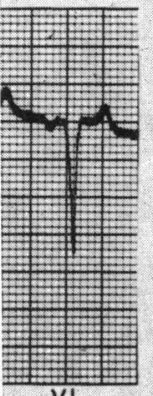

VI

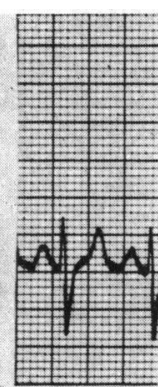

II

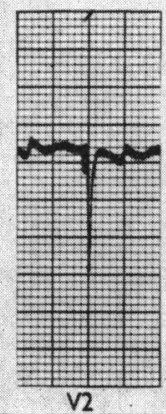

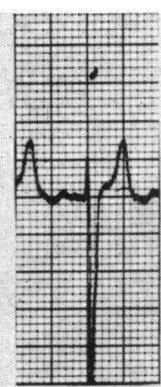

111

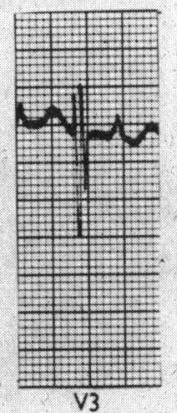

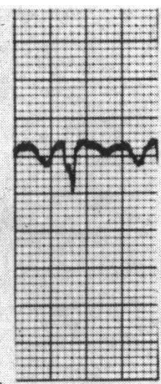

aVR

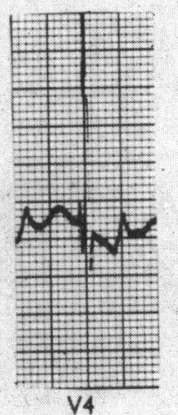

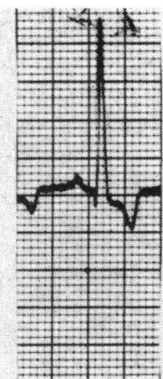

aYL

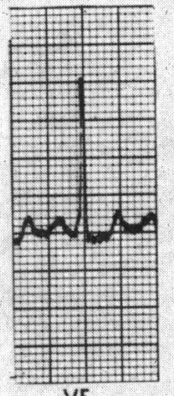

V5

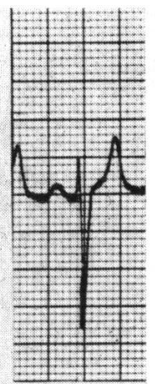

aVF

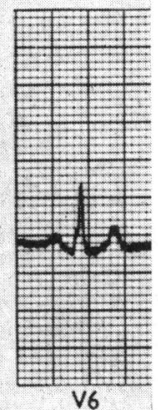

FIG. 2.-Electrocardiogram of Patient 28, at 8 years, showing left ventricular dominance and left axis deviation.

in 9 , left ventricular hypertrophy in 1 , and combined hypertrophy in 4.

In the group of 8 with a ventricular septal defect and pulmonary stenosis, right ventricular hypertrophy was present in 6, left hypertrophy in 1 (Fig. 2), and combined hypertrophy in 1.

In the whole group of 31 patients, normal ventricular hypertrophy pattern was present in 3, right ventricular hypertrophy in 20, left ventricular hypertrophy in 2, and combined hypertrophy in 6.

5. Morphology of $Q R S$ in Pracordial Leads (31 patients). Lead V1 showed a pattern of $\mathrm{rsR}^{\prime}$ in 4, $\mathbf{r S r}^{\prime}$ in $1, \mathbf{R s R}^{\prime}$ in 1 (Fig. 3), and rsR's' in 1 . Slurring of the $R$ wave in lead VI was present in 4 others. All 11 patients had a ventricular septal defect, which was also associated with pulmonary stenosis in 5 .

In the whole group, a $Q$ wave in V1 which measured $1 \mathrm{~mm}$. in depth was observed in 2 patients, and $2-3 \mathrm{~mm}$. in 2 . The first 2 patients had a ventricular septal defect, while the last 2 had a closed ventricular septum. In 1 of the 2 with a closed ventricular septum, QS waves in V2-3 measured 5-10 mm. in depth (Patient 8: Fig. 4). A QS pattern in lead V1 was observed in 1 patient with a ventricular septal defect and pulmonary stenosis (Patient 28).

In the whole group a $Q$ wave in lead V6, which measured $1 \mathrm{~mm}$. in depth, was observed in 7 patients, $2 \mathrm{~mm}$. in $2,3 \mathrm{~mm}$. in $1,4 \mathrm{~mm}$. in 1 , and $5 \mathrm{~mm}$. in 1 . Of these 12 patients, 3 had a closed ventricular septum, 8 had a ventricular septal defect without pulmonary stenosis, and 1 had a ventricular septal defect with pulmonary stenosis. Other than the group of 8 with a ventricular septal defect without pulmonary stenosis, 2 patients had a QS pattern in V6 (Patients 18 and 23). Two other patients with a ventricular septal defect and pulmonary stenosis, other than the one with this diagnosis, developed a $Q$ wave in V6 after pulmonary valvotomy in 1 (Patient 27) and Blalock's anastomosis in the other (Patient 32).

6. Ventricular Hypertrophy Pattern Correlated to Axis Deviation (31 patients). Among the 3 patients whose præcordial leads showed a normal ventricular hypertrophy pattern, 2 had right axis deviation, and 1 had a normal axis deviation (Patient 1 ).

Of the 20 patients whose præcordial leads showed a pattern of right ventricular hypertrophy, 19 had right axis deviation, and 1 had an indeterminate axis (Patient 16).

Of the 2 whose præcordial leads showed a pattern of left ventricular hypertrophy, 1 had right axis deviation (Patient 13), and 1 had left axis deviation (Patient 28).

Of the 6 with biventricular hypertrophy, 3 had right axis deviation (Patients 22, 25 and 26), 1 had 

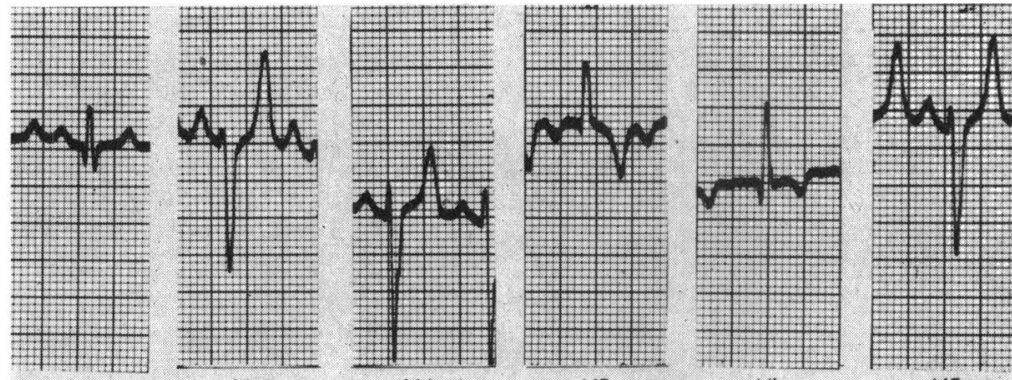

111

aVR

aVL

$\mathrm{aVF}$
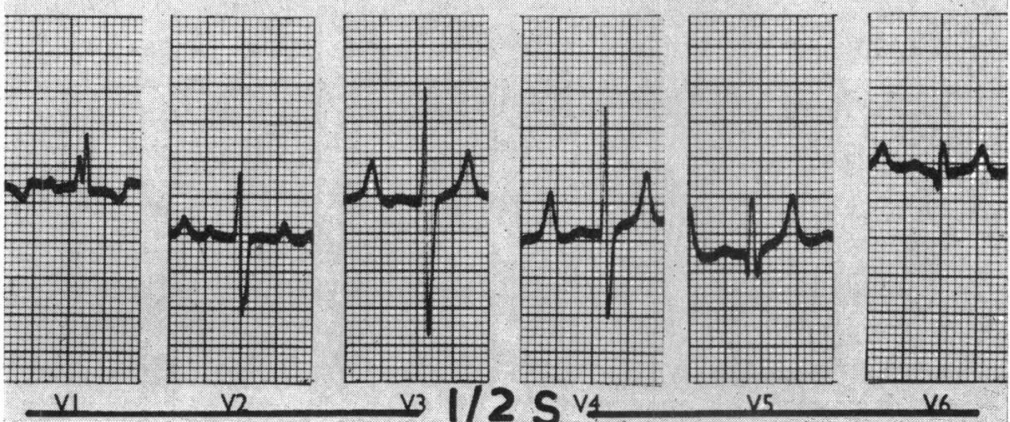

FIG. 3.-Electrocardiogram of Patient 20, at 15 years, showing combined ventricular hypertrophy, left axis deviation, and $\mathbf{R s R}^{\prime}$ pattern in V1.

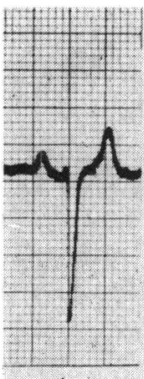

1

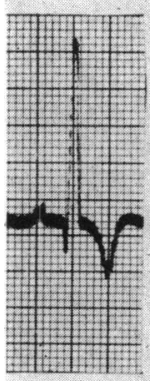

VI

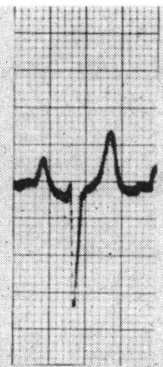

II

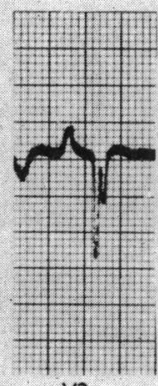

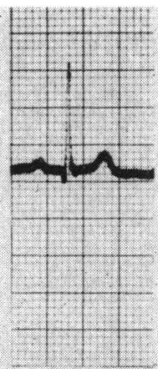

111

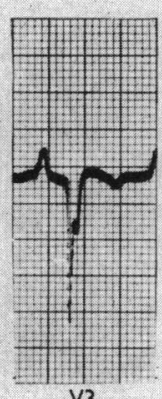

V3

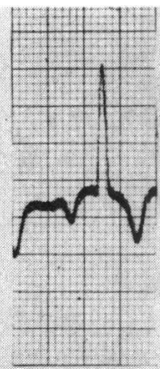

aVR

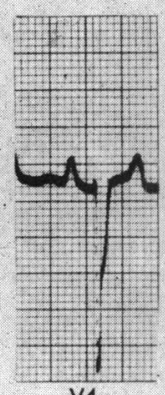

V4

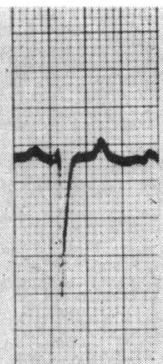

aVL

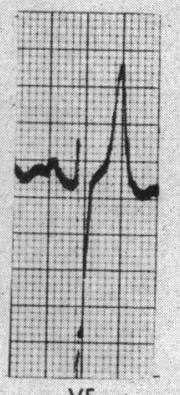

V5
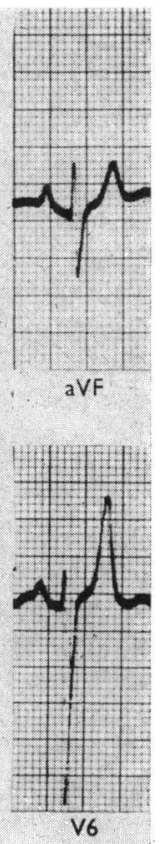

Frg. 4.-Electrocardiogram of Patient 8 , at $10 \frac{1}{2}$ years, showing right ventricular hypertrophy, deep QV1 and QS waves in V2-3, and right axis deviation. 
left axis deviation (Patient 20), 1 had a normal axis (Patient 10), and in 1 the axis was indeterminate (Patient 5).

7. TWave Changes. (a) Limb leads (33 patients): Generalized $T$ wave inversion was present in the limb leads of 2 patients (Patients 3 and 12), and in lead I only in 3 with a ventricular septal defect (Patients 23, 24, and 28). The first 2 patients were on digitalis at the time of recording the electrocardiogram.

(b) Pracordial leads (31 patients). In the whole group of 31 patients, higher $T$ waves in the right præcordial leads than those in the left leads were present in 3 (Patients 4, 13, and 21), and higher in the left than in the right in 2 (Patients 2 and 16). Notching of the $T$ waves in the left præcordial leads was observed in 1 (Patient 9).

\section{Discussion}

1. Rhythm. The present series suggests that chronic abnormalities of rhythm and conduction are uncommon in complete transposition of the great vessels. In contrast to the relatively frequent occurrence of complete heart block in inverted complete transposition (corrected transposition) (Anderson, Lillehei, and Lester, 1957; Schiebler et al., 1961; and others), complete atrio-ventricular dissociation was not seen in any patient in this series. Paul, Myers, and Campbell (1951), and Sodi-Pallares and Calder (1956) state that complete heart block has been reported in complete transposition of the great vessels, but review of earlier reported supposed cases shows that Case 2 of Abbott (1936, p. 56) and patient of Aitchison, Duthie, and Young (1955), were associated with single ventricle. That reported by Dickson and Jones (1948) is an example of complete transposition with single ventricle, with a rudimentary chamber and tricuspid atresia. In Case 2 of Ingham and Willius (1938), there was corrected transposition of the great vessels in mirror-image dextrocardia. The occurrence of heart block in single ventricle has been discussed elsewhere (Shaher, 1963). Since Case 10 of Lev and Rowlatt (1961) had complete transposition with inversion of the ventricles, and complete heart block, it appears that the occurrence of this disturbance of conduction in complete (non-inverted) transposition of the great vessels raises two possibilities: (1) the presence of single ventricle, and (2) the presence of inversion of the ventricles. As no authenticated case with normally situated ventricles seems to have been reported, this combination should be regarded as being rare if it occurs at all.

2. $P$ Waves. The present series confirms the earlier observation of Martins de Oliveira and Zimmerman (1959), and of Elliott et al. (1963a), that the frontal projection of the $P$ vector is usually within normal limits.

If we accept a height of the $P$ wave of $2 \mathrm{~mm}$. as being within the normal range, then in the whole group of 33 patients, abnormally tall $P$ waves were present in 29 patients, i.e. 88 per cent. Of these, 7 had a closed ventricular septum $(80 \%$ of this group), 14 had a ventricular septal defect without pulmonary stenosis ( $88 \%$ of this group), and $8 \mathrm{had}$ a ventricular septal defect with pulmonary stenosis ( $100 \%$ of this group). Only 2 patients in the whole series, who had a ventricular septal defect without pulmonary stenosis, exceeded the upper limit of the duration of the $P$ waves (Patients 20 and 21).

In the group of 5 patients reported by Martins de Oliveira and Zimmerman (1959) (details of the ventricular septum and of the left ventricular outflow not specified), the duration of the $P$ wave was increased to $0.11 \mathrm{sec}$. in 2 , the amplitude varied from 1.9 to $4.5 \mathrm{~mm}$., and peaking was present in all 5 cases. In the group of 48 patients reported by Noonan et al. (1960), abnormal P waves were present in 30 and tended to become more abnormal with increasing age. Elliott et al. (1963a) divided their patients into those with a small communication (27), and those with a large communication (21). In their first group the $P$ waves were abnormal in 12 of the 27, while in their second group they were abnormal in 14 patients. The last two groups of authors, however, did not specify the criteria for identifying abnormal $P$ waves in their cases and accordingly the findings in this series cannot be compared directly to their findings.

3. $P-R$ Interval. No definite conclusions could be drawn from the $P-R$ interval, but longer $P-R$ intervals tended to occur in older patients.

4. Electrical Axis. The present series suggests that normal axis deviation probably occurs only in some infants less than 1 year of age, older children and adults almost always having an abnormal axis. Thus of the 13 patients whose age was 1 year or less, 3 had normal axis deviation, while all the 20 patients above the age of 1 year had an abnormal axis. Of the whole group, 80 per cent had right axis deviation, and only $2(6 \%)$ had left axis deviation. Each of the last 2 had an associated ventricular septal defect.

5. Duration of $Q R S(V I)$. No conclusion could be drawn from the duration of the QRS, but it seemed that while a short duration of 0.04-0.06 sec. may occur in younger patients, a duration of $0.08 \mathrm{sec}$. or more is likely in older patients regardless of the anatomy of the ventricular septum. 
6. Pracordial Leads. Among the different præcordial patterns only 2 could be correlated to the pathology of the ventricular septum. Thus, while a pattern of left ventricular hypertrophy was observed in 2 with a ventricular septal defect, and a pattern of partial right bundle-branch block, or slurring of the $R$ in V1, was observed in 11 patients with a ventricular septal defect, none of the 9 with a closed ventricular septum showed either of these 2 patterns. Partial right bundle-branch block occurred in 14 per cent (Keith et al., 1958), and in 37 per cent (Noonan et al., 1960) of cases associated with a ventricular septal defect. The latter authors pointed out that hypertrophy of both ventricles, or of the left ventricle alone, was the rule in patients with a ventricular septal defect and large pulmonary blood flow. These 2 patterns, however, should be regarded as being suggestive only of a ventricular septal defect, for the case of transposition of the great vessels with a closed ventricular septum reported by Pung, Gottstein, and Hirsch (1955) showed "left heart preponderance". Moreover, for reasons which will be discussed later, partial right bundle-branch block or slurring of the $R$ wave in V1 may be expected in some patients with a closed septum.

Whereas a pattern of biventricular hypertrophy was observed in 1 patient with a closed ventricular septum in this series, 5 patients with a ventricular septal defect showed this pattern. Combined ventricular hypertrophy was not observed in patients with a closed ventricular septum in Noonan et al.'s (1960) series, but among their patients with a ventricular septal defect, 13 showed this electrocardiographic pattern. In Elliott et al.'s (1963a) series, cases with a ventricular septal defect were associated with biventricular hypertrophy at least twice as frequently as were cases with a closed ventricular septum. These findings suggest that electrocardiographic signs of biventricular hypertrophy tend to be associated with a ventricular septal defect rather than with a closed ventricular septum.

Keith et al. (1958) observed a qR pattern in V1 in 3 of their patients: 2 with single ventricle and 1 with a closed ventricular septum. Elliott et al. (1963a) pointed out that in their series a $Q$ wave was seen in V1 only in patients with a small communication. In this series, though deep $Q$ waves in V1 were observed only in 2 patients with a closed ventricular septum, 2 patients with a ventricular septal defect had a small QV1.

Watson and Keith (1962) found Q waves of $2 \mathrm{~mm}$. or more in lead V6 in 15 per cent of their patients with complete transposition of the great vessels (anatomy of ventricular septum not specified), while Elliott et al. (1963a) observed it in 15 per cent of U+ their patients with a small communication, and in 85 per cent with a large communication. In this series a $Q$ wave of $1 \mathrm{~mm}$. or more was observed in 12 patients (3 with a closed ventricular septum), but of these only 4 had a QV6 of $2 \mathrm{~mm}$. or more (one with a closed ventricular septum). These findings suggest that a $Q$ wave in lead V6 probably favours a diagnosis of ventricular septal defect.

Although no pattern could be correlated to the present absence of pulmonary stenosis, cases without pulmonary stenosis tended to show a pattern of biventricular hypertrophy, whereas cases with pulmonary stenosis tended to show a pattern of isolated right ventricular hypertrophy. Thus, in this series only 1 patient with pulmonary stenosis showed combined ventricular hypertrophy pattern, while 4 without pulmonary stenosis had it. This has also been suggested earlier by Noonan et al. (1960) who pointed out that patients with a ventricular septal defect and large pulmonary blood flow usually have hypertrophy of both ventricles or the left ventricle alone.

Keith et al. (1958) pointed out that whereas at birth the electrocardiogram was usually within normal limits in uncomplicated cases of transposition, complex forms always had pathological changes. When death occurs early the electrocardiogram may remain normal or only slightly changed. They stressed that signs of right ventricular hypertrophy in the newborn infant might only be represented by the presence of upright $T$ waves in the præcordial leads. They thought that the statement of Campbell and Suzman (1951) and Astley and Parsons (1952) that the electrocardiogram in transposition was indistinguishable from that in Fallot's tetralogy, was valid only in older children and adolescents with transposition. The findings in this series support this opinion, for of the 3 patients with a normal ventricular præcordial pattern (except for the presence of digitalis effect) 2 were under the age of 3 months.

In the present series a pattern of right ventricular hypertrophy was seen in 64 per cent of the patients, left ventricular hypertrophy in 6 per cent, combined ventricular hypertrophy in 20 per cent, and a normal pattern in 10 per cent. Among the 53 patients with complete transposition reported by Calleja and Hosier (1960), right ventricular hypertrophy was present in 60 per cent, left ventricular hypertrophy in 15 per cent, and combined ventricular hypertrophy in 9 per cent. They considered the electrocardiogram normal in 13 per cent. The pattern of ventricular hypertrophy in the $\mathbf{4 8}$ patients reported by Noonan et al. (1960) is as follows: right ventricular hypertrophy in 60 per cent, combined ventricular hypertrophy 21 per cent, left ventricular hyper- 
trophy 13 per cent, and a normal pattern in 6 per cent. On the other hand, in the group of 54 patients reported by Elliott et al. (1963a), right ventricular hypertrophy was present in 52 per cent, combined ventricular hypertrophy in 45 per cent, left ventricular hypertrophy in 1.5 per cent, and Wolff-Parkinson-White syndrome in 1.5 per cent.

In 1955 Anderson and Adams pointed out that patients with a ventricular septal defect frequently show the amplitude of the $R$ waves in lead V1 to be less than 75 per cent of the total RS amplitude. When the $R$ waves in lead V1 approach 100 per cent of the total RS amplitude, absence of such defect is indicated. Keith et al. (1958) thought that these electrocardiographic patterns were seen more often in infants than in older age-groups. In this series no attempt has been made to study the height of the $R$ waves in relation to the total $R S$ amplitude in lead V1, for 12 patients with a ventricular septal defect had no $S$ wave in this lead.

7. TWave Changes. The present series suggests that the commonest $T$ wave abnormality in complete transposition of the great vessels is negativity in the right præcordial leads in adults and positivity in these leads in infants and children. Zuckermann, Cisneros, and Novelo (1951) suggested that negative $T$ waves in the left præcordial leads and positive $T$ waves in the right præcordial leads occurred in transposition. Among the 48 patients of Noonan et al. (1960), 40 per cent had a normally inverted $T$ wave in lead V4R, but 60 per cent had a normally upright $T$ wave in lead V6. A flattened biphasic or inverted $T$ wave in lead V6 occurred in 8 of their 12 cases with a ventricular septal defect and large pulmonary blood flow. Sodi-Pallares et al. (1958a, b) suggested other $T$ wave changes in transposition: first, higher positive $T$ waves in the right than in the left præcordial leads; secondly, normal positive $T$ waves in V1 and V2 and flat $T$ waves in V5 and V6, and thirdly, notched $T$ waves in the left præcordial leads. In the present series only 3 patients had higher $T$ waves in the right præcordial leads than those in the left, while 1 had notching of the $T$ waves in V5-6. In the group of 54 patients of Elliott et al. (1963a), notched T waves in lead V6 were seen in 2, and positive $T$ waves higher in the right præcordial leads than in the left præcordial leads in 9.

8. Systolic and Diastolic Overloading of Right and Left Ventricles. Cabrera and Monroy (1952) and Cabrera and Gaxiola (1959) studied the relation between the electrocardiogram and the haemodynamics in heart disease in general, and described patterns for the electrocardiographic recognition of systolic and diastolic overloading of the right and left ventricles. In systolic overloading of the heart stronger contractions occur because of increased resistance to ejection of blood. Diastolic overloading indicates an increase of the volume of blood filling the ventricle during diastole. The electrocardiographic pattern of systolic overloading of the left ventricle is characterized by delayed repolarization of that ventricle, producing a negativity of the $T$ waves and/or S-T segment in the left ventricular leads. Diastolic overloading of the left ventricle is recognized by the high delayed $R$ wave in V5 and V6 with deep S waves in V2 and V3, and high positive $T$ wave in V5 and V6. Systolic overloading of the right ventricle increases the voltage of the $R$ wave in V1, and the QRS in this lead may present an RS, Rs, or qR pattern, with or without slurring or notching of the $R$ wave. Diastolic overloading of the right ventricle is recognized by the presence of RSR' $^{\prime}$ or multiphase QRS pattern in V1. Agustsson, DuShane, and Swan (1957) pointed out that diastolic overloading of the left ventricle might be represented by deep $Q$ waves and tall $R$ waves and tall peaked upright $T$ waves in leads II, III, VF, and V6. Systolic overloading of the left ventricle may be presented by an initial $Q$ wave followed by tall $\mathbf{R}$ waves, with intrinsicoid deflection greater than $0.04 \mathrm{sec}$, and associated with flattened or inverted $T$ waves in these leads. Luna and Crow (1961) correlated the degree of pulmonary hypertension to the morphology of the QRS in lead VI. When the right ventricular pressure was greater than the left ventricular pressure, 75 per cent of their cases had a $\mathrm{qR}$ pattern. With balanced ventricular pressure, 77 per cent had an initial slurring of the upstroke of the $R$ wave. When the pressure in the left ventricle exceeded that in the right ventricle, 75 per cent of their tracings had a clean $R$ wave. Watson and Keith (1962) confirmed the concept that a deep $Q$ wave in the left præcordial leads was one of the features of left ventricular diastolic overloading and stressed that a QV6 was the most frequent single indication of left ventricular diastolic overloading, and a change in its depth was a most useful indication of a change in the left ventricular diastolic overloading. They pointed out that this sign was more characteristic of left ventricular diastolic overloading than tall peaked $T$ waves, the latter being frequently absent even in the presence of clear evidence of left ventricular diastolic overload. In their view the amplitude of the $R$ in V6 increased in both left ventricular systolic and diastolic overloading, whereas QV6 was either normal or diminished in left ventricular systolic overloading.

If the electrocardiogram in complete transposition of the great vessels is to be viewed from a hœmo- 
dynamic point, 3 haemodynamic facts must be stressed:

(1) In all patients with a large ventricular septal defect, with or without pulmonary stenosis or pulmonary vascular obstruction, the pressure in the two ventricles is equal and is at systemic level.

(2) In all cases with a closed ventricular septum, the pressure in the right ventricle is at systemic level.

(3) In most cases with a closed ventricular septum the left ventricular pressure is lower than that in the right ventricle. Only in the rare instances when severe pulmonary stenosis, or severe pulmonary vascular obstruction without a large patent ductus arteriosus, is associated with a closed ventricular septum, may the pressure in the left ventricle be higher than that in the right.

Accordingly, all cases of transposition have systolic overloading of the right ventricle. By definition, systolic overloading of the left ventricle means the development of a systolic pressure higher than nor$\mathrm{mal}$ in the cavity of this ventricle. Except in the rare case already mentioned, systolic overloading of the left ventricle does not occur in complete transposition. Electrocardiographically, therefore, the basic pattern of complete transposition is that of systolic overloading of the right ventricle. Correlating this to the finding of Luna and Crow (1961), a deep $Q$ wave in lead V1 may occur in patients with a closed ventricular septum, while slurring of the $R$ wave in this lead may occur in patients with a large ventricular septal defect.

It has been shown elsewhere (Shaher, 1964b) that a large pulmonary or systemic blood flow, which is not a function of blood shunting, may occur in transposition. Accordingly, electrocardiographic evidence of diastolic overloading of either (rarely both) ventricle may be superimposed on the two basic right ventricular overload patterns. With diastolic overloading of the left ventricle deep $Q$ waves and tall $R$ waves make their appearance in $V 6$. With diastolic overloading of the right ventricle, multiphasic QRS patterns in V1 may occur. Thus, whereas cases with large pulmonary blood flow tend to show evidence of diastolic overloading of the left ventricle, cases with severe pulmonary stenosis do not usually show this pattern, hence the frequent association of biventricular hypertrophy in the former, and isolated right ventricular hypertrophy in the latter. Since, as pointed out earlier, systolic overloading of the right ventricle is present in all cases of transposition, the occurrence of patients who do not show systolic overloading of this ven- tricle remains unexplained, e.g. Patients 20 and 28 (Fig. 2). As systolic overloading of the left ventricle does not occur except under very special circumstances, and, as pointed out by Noonan et al. (1960), T wave inversion in V6 is seen mostly in patients with a ventricular septal defect and large pulmonary blood flow, the occurrence of this pattern in transposition is better explained on the basis of left ventricular myocardial ischaemia.

9. Size of Associated Defects and the Electrocardiogram. Elliott et al. (1963a) studied the electrocardiogram in complete transposition, in relation to the size of the associated defects. They divided their patients into those with a "small communication", and those with a "large communication". It seemed important to them "to work from a functional rather than from a primary anatomic point of view, and to consider the influence of absence or presence of flow through the ductus arteriosus, as well as through the ventricular septum". It has been shown elsewhere (Shaher, 1964b) that the pulmonary and the systemic blood flows are not a function of blood shunting in complete transposition. Moreover, whereas the pulmonary and the systemic blood flows vary within a wide range, the shunt (effective pulmonary blood flow) in each case is small and limited and varies within a narrow range. With these points in mind, it is difficult to see how variations in the size of the communication would produce variable electrocardiographic patterns. Moreover the interpretation of anatomy in terms of flow is difficult to accept, since a large ductus arteriosus or a large ventricular septal defect with transposition of the great vessels does not necessarily mean a large amount of blood flowing through it, and the mechanism by which an alteration in the size of defect would bring about a different electrocardiographic pattern has not been explained. Since the amount of blood exchanged between the two circuits (effective pulmonary blood flow) in transposition is always small, a specific electrocardiographic pattern of a large communication is not related to the amount of blood passing through it, but is related to the equalization of pressure in the two ventricles, which occurs under such circumstances. Similarly a specific electrocardiographic pattern of the group with a small communication is related to the higher pressure in the right ventricle than that in the left ventricle, which occurs in most patients in this group. These two electrocardiographic patterns may or may not be modified by diastolic overloading patterns of either or both ventricles. The following case history of Patient 27 illustrates some of these points. This patient, a girl of 8, had a pulmonary valvotomy in 1957. 


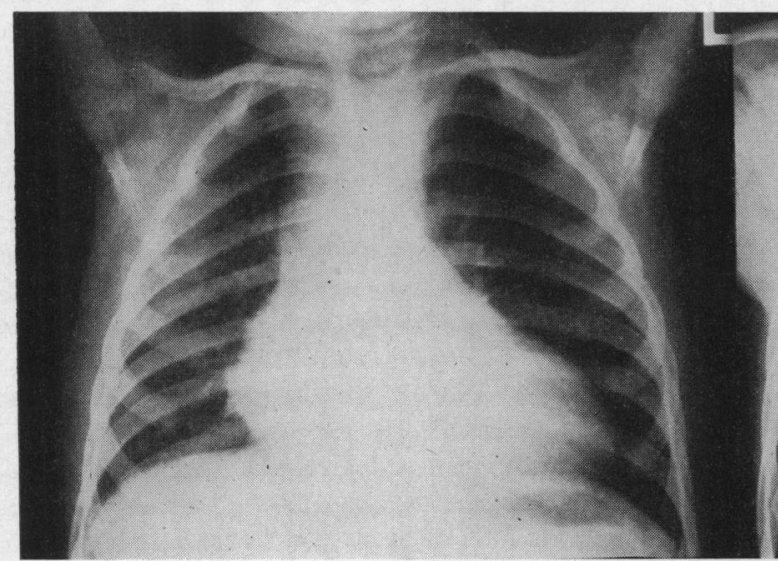

A

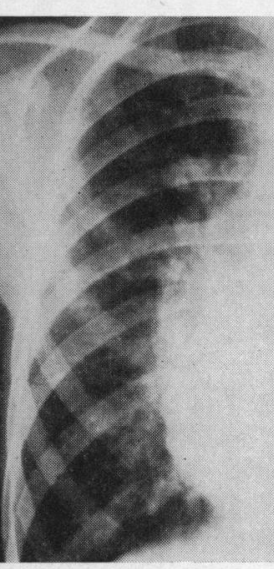

$\mathrm{B}$

Fig. 5A.-Chest radiograph of Patient 27, in 1957, before pulmonary valvotomy. There is cardiac enlargement and pulmonary ischæmia.

FIG. 5B.-Chest radiograph of Patient 27, three years after pulmonary valvotomy. There is more cardiac enlargement and the lung fields show pulmonary plethora.

Before operation she was intensely cyanosed and the electrocardiogram showed isolated right ventricular hypertrophy. Little improvement in cyanosis followed operation, but the chest radiograph showed more cardiac enlargement, and pulmonary plethora was noted for the first time (Fig. 5A and B). The post-operative electrocardiogram showed biventricular hypertrophy with the development of $Q$ waves and tall $R$ waves in V6 (Fig. 6a and b).

\section{SUMMARY}

The electrocardiograms of 33 patients with complete transposition of the great vessels have been studied. Patients were divided into 3 groups

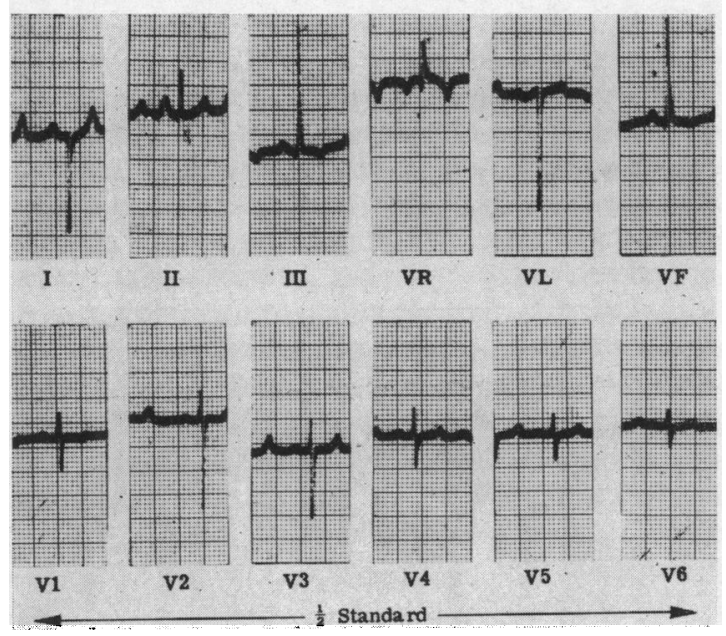

FIG. 6`.-Electrocardiogram of Patient 27, in 1957, before puln onary valvotomy, showing right ventricular hypertrophy. according to the presence or absence of a ventricular septal defect or pulmonary stenosis. Although no definite pattern could be correlated with these defects, the presence of a $\mathrm{qR}$ pattern in V6, combined ventricular hypertrophy, and an rsR' pattern in V1, was thought to suggest a ventricular septal defect, while isolated right ventricular hypertrophy and a $\mathrm{qR}$ pattern in V1 pointed to a closed ventricular septum. Left axis deviation was observed in 2 patients with a ventricular septal defect, one of whom had pulmonary stenosis. Cases with pulmonary stenosis were likely to be associated with isolated right ventricular hypertrophy. An attempt has been made to explain the electrocardiogram on

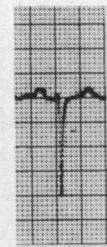

I

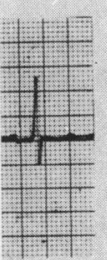

v1

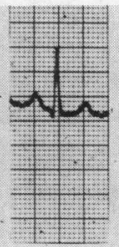

II

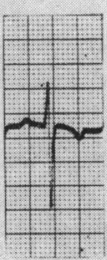

V2

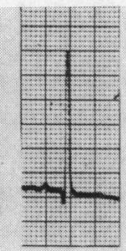

III

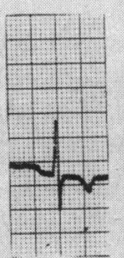

V3

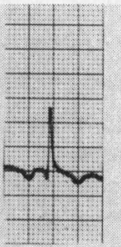

VR

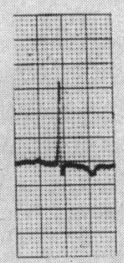

V4.

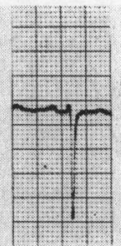

VL

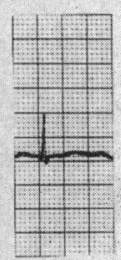

v5

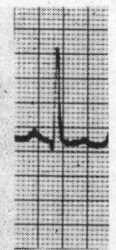

VF

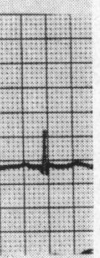

V6
Fig. 6b.-Electrocardiogram of Patient 27, three years after pulmonary valvotomy, showing combined ventricular hypertrophy and the appearance of QV6. 
a hæmodynamic basis, and it.was concluded that while systolic overloading of the right ventricle occurs in all cases of transposition, systolic overloading of the left ventricle is most uncommon.

Two basic electrocardiographic patterns of systolic overloading of the right ventricle in transposition have been described. These may or may not be modified by diastolic overloading of either or both ventricles.

Our thanks are due to Dr. A. M. Johnson for permission to study his patients from Southampton Chest Hospital.

\section{REFERENCES}

Abbott, M. E. (1936). Atlas of Congenital Cardiac Disease. American Heart Association, New York.

Agustsson, M. G., DuShane, J. W., and Swan, H. J. C. (1957). Ventricular septal defect in infancy and childhood. Clinical and physiologic study of 19 cases. Pediatrics, 20, 848.

Aitchison, J. D., Duthie, R. J., and Young, J. S. (1955). Palpable venous pulsations in a case of transposition of both arterial trunks and complete heart block. Brit. Heart F., 17, 63.

Anderson, R. C., and Adams, P., Jr. (1955). Differentiation of associated cardiac defects in transposition of the great vessels. F.-Lancet, 75, 60.

—, Lillehei, C. W., and Lester, R. G. (1957). Corrected transposition of the great vessels of the heart. A review of 17 cases. Pediatrics, 20, 626.

Astley, R., and Parsons, C. (1952). Complete transposition of the great vessels. Brit. Heart f., 14, 13.

Cabrera, E., and Gaxiola, A. (1959). A critical re-evaluation of systolic and diastolic overloading patterns. Progr. cardiovasc. Dis., 2, 219.

- and Monroy, J.R. (1952). Systolic and diastolicloading of the heart. 1. Physiologic and clinical data. Amer. Heart F., 43, 661 .

Calleja, H. B., and Hosier, D. M. (1960). Complete transposition of the great vessels: An electrocardiographic and anatomic correlation. Circulation, 22, 730.

,-- , and Grajo, M. Z. (1965). The electrocardiogram in complete transposition of the great vessels. Amer. Heart f., 69, 31.

Campbell, M., and Suzman, S. (1951). Transposition of the aorta and pulmonary artery. Circulation, 4, 329.

Dack, S. (1960). The electrocardiogram and vectorcardiogram in ventricular septal defect. Amer. F. Cardiol., 5, 199.

Dickson, R. W., and Jones, J. P. (1948). Congenital heart block in an infant with associated multiple congenital cardiac malformations. Amer. F. Dis. Child., 75, 81.

Elliott, L. P., Anderson, R. C., Tuna, N., Adams, P., Jr., and Neufeld, H. N. (1963a). Complete transposition of the great vessels. II. An electrocardiographic analysis. Circulation, 27, 1118.

—, Taylor, W. J., and Schiebler, G. L. (1963b). Combined ventricular hypertrophy in infancy. Vectorcardiographic observations with special reference to the Katz-Wachtel phenomenon. Amer. F. Cardiol., 11, 164.

Ingham, D. W., and Willius, F. A. (1938). Congenital transposition of the great arterial trunks. Amer. Heart $\mathcal{f}$., $15,482$.

Katz, L. N., Langendorf, R., and Pick, A. (1952). Introduction to the Interpretation of the Electrocardiogram. University of Chicago Press, Chicago.
Keith, J. D., Rowe, R. D., and Vlad, P. (1958). Heart Disease in Infancy and Childhood. Macmillan, New York.

Kossman, C. E., and Johnston, F. D. (1935). The precordial electrocardiogram. I. The potential variations of the precordium and of the extremities in normal subjects. Amer. Heart f., 10, 925.

Lev, M., and Rowlatt, U. F. (1961). The pathologic anatomy of mixed levocardia. A review of thirteen cases of atrial or ventricular inversion with or without corrected transposition. Amer. F. Cardiol., 8, 216.

Luna, R. L., and Crow, E. W. (1961). Correlation of degree of pulmonary hypertension with morphology of the QRS in lead V1 in cases with evidence of systolic overloading of the right ventricle. Amer. Heart f., 62, 481.

Martins de Oliveira, J., and Zimmerman, H. A. (1959). Auricular overloadings. Electrocardiographic analysis of 193 cases. Amer. F. Cardiol., 3, 453.

Noonan, J. A., Nadas, A. S., Rudolph, A. M., and Harris, G. B. C. (1960). Transposition of the great arteries. A correlation of clinical, physiologic and autopsy data. New Engl. F. Med., 263, 592.

Paul, O., Myers, G. S., and Campbell, J. A. (1951). The electrocardiogram in congenital heart disease. Circulation, 3, 564.

Pung, S., Gottstein, W. K., and Hirsch, E. F. (1955). Complete transposition of great vessels in a male aged 18 years. Amer. F. Med., 18, 155.

Schiebler, G. L., Edwards, J. E., Burchell, H. B., DuShane, J. W., Ongley, P. A., and Wood, E. H. (1961). Congenital corrected transposition of the great vessels: A study of 33 cases. Pediatrics, 27, 851.

Scott, O., and Franklin, D. (1963). The electrocardiogram in the normal infant. Brit. Heart $\mathcal{F} ., 25,441$.

Shaher, R. M. (1963). The electrocardiogram in single ventricle. Brit. Heart f., 25, 465.

(1964a). Complete and inverted transposition of the great vessels. Brit. Heart $\mathcal{F}$., 26, 51.

(1964b). The haemodynamics of complete transposition of the great vessels. Brit. Heart f., 26, 343.

and Johnson, A. M. (1963). Isolated lævocardia and isolated dextrocardia. Pathology and pathogenesis. Guy's Hosp. Rep., 112, 127.

Sodi-Pallares, D., and Calder, R. M. (1956). New Bases of Electrocardiography. Mosby, St. Louis.

- Pileggi, F., Cisneros, F., Ginefra, P., Portillo, B., Medrano, G. A., and Bisteni, A. (1958a). The mean manifest electrical axis of the ventricular activation process (AQRS) in congenital heart disease: a new approach in electrocardiographic diagnosis. Amer. Heart f., 55, 681.

, Portillo, B., Cisneros, F., de la Cruz, M. V., and Acosta, A. R. (1958b). Electrocardiography in infants and children. Pediat. Clin. N. Amer., 5, 871.

Vince, D. J., and Keith, J. D. (1961). The electrocardiogram in ventricular septal defect. Circulation, 23, 225.

Watson, D. G., and Keith, J. D. (1962). The $Q$ wave in lead V6 in heart disease of infancy and childhood, with special reference to diastolic overloading. Amer. Heart F., $63,629$.

Wood, P. (1956). Diseases of the Heart and Circulation, 2nd ed. Eyre and Spottiswoode, London.

Ziegler, R. F. (1951). Electrocardiographic Studies in Normal Infants and Children. Charles C. Thomas, Springfield, Illinois.

Zuckermann, R., Cisneros, F., and Novelo, S. (1951). E1 electro cardiograma en algunas cardiopatias congénitas. Arch. Inst. cardiol. México, 21, 61. Cited by Elliott et al. (1963a). 